DOI 10. 18307/2017. 0622

(C) 2017 by Journal of Lake Sciences

\title{
南北同枯场景下南水北调中线丹江口水库供水调度方式”
}

\author{
张 点, 孟明星, 蔡淑兵, 饶光辉 \\ (长江勘测规划设计研究院,武汉 430010)
}

\begin{abstract}
摘 要: 南北同枯场景下南水北调中线丹江口水库供水调度是保障水源工程有效供给、优化配置供水水源的重要课题, 如何科学制定不同供水对象的供水水量、兼顾水源区及受水区用水需求、充分发挥丹江口水利枢纽的调蓄作用, 是南水 北调中线工程功能效益发挥的关键. 以南水北调中线水源工程丹江口水库为研究对象, 深人分析了中线工程通水后丹江 口水库供水现状及面临的技术难题, 从而提出南北同枯场景的判别标准及相应水库供水调度的方法, 揭示了汉江中下 游、清泉沟和南水北调中线供水对水库起始供水水位的响应机理, 提出 “蓄丰补枯、均衡减少” 的方法是南北同枯场景下 丹江口水库的供水调度方式, 不同供水起始水位及供水方式情况下供水调度仿真结果表明, 本文所得结论可为丹江口水 库在实际运行中制定调度方案提供参考.
\end{abstract}

关键词: 南水北调中线;南北同枯;丹江口水库;供水调度

\section{Water supply operation of Danjiangkou Reservoir of South-north water diversion project in the middle line under water shortage of South and North}

ZHANG Rui, MENG Mingxing, CAI Shubing \& RAO Guanghui

(Changjiang Institute of Survey, Planning, Design and Research, Wuhan 430010, P.R.China)

Abstract: The method of water supply operation for Danjiangkou Reservoir is important for getting more benefit by South-north water diversion project in the middle line. The key of this method is to control water supply of each object so as to balance the demand between water resource area and water-receiving area, as well as give full play to the key role of controlling reservoirs. It is necessary to put forward an effective scheme to meet the requirement of operation under water shortage of South and North. In this paper, a water supply declining control scheme under water shortage of South and North is proposed based on the analysis of present situation. The research of influence by initial water level is implemented to find the warning water level. The water supply declining control scheme under water shortage of South and North is proposed and the corresponding results are calculated. The results of this study can be used for making the operation scheme of Danjiangkou Reservoir in the middle route in the south-to-north water diversion project.

Keywords: South-north water diversion project in the middle line; water shortage of South and North; Danjiangkou Reservoir; operation of water supply

南北同枯是指,在南水北调等大型跨流域引调水工程运行阶段, 当地处不同流域地区、水文情势相对独 立的水源区和受水区同时遭遇连续枯水年或枯水时段, 导致水源工程在预见期内降雨径流和存蓄水量无法 同时满足水源区和受水区正常用水要求,生活、生产、生态用水安全遭到较大影响的极端气候条件. 南北同 枯这一恶劣气候条件对跨流域调水工程的正常运行和水源区、受水区社会经济和谐稳定带来了极大挑战. 因此,如何科学控制水源工程的供水调度方式、统筹协调水源区及受水区用水需求、充分发挥引调水工程中 控制性水利枢纽的调蓄作用,是南北同枯场景下水库供水调度的关键科学问题.

南水北调中线工程是解决我国水资源分布与社会生产力布局不相适应的矛盾,促进华北地区经济繁荣 和社会发展,保护生态环境的有效途径,也是缓解京、津、冀、豫城市用水紧张状况,控制地下水严重超采,保

* 国家重点研发计划(2016YFC0400907) 资助. 2017-02-19 收稿; 2017-03-29 收修改稿. 张睿( 1987 ), 男, 高 级工程师, 博士;E-mail: ruiz6551@ foxmail.com. 
障缺水地区社会经济和谐稳定发展的战略性水利工程. 丹江口水库作为南水北调中线的供水水源工程,也 是汉江综合利用开发治理的控制性水利枢纽, 具有防洪、供水、发电、航运等综合利用效益. 丹江口水利枢纽 分初期规模和后期规模两期兴建, 初期工程于 1973 年底建成, 后期的大坝加高工程于 2005 年开工建设, 2014 年 12 月 12 日丹江口水库正式向北方供水, 标志着丹江口水库后期规模全面转人正常运行期. 2016 年 10 月, 水利部批复了《丹江口水利枢纽调度规程 (试行)》, 为丹江口后期规模正常运用调度提供了权威性 指导.

丹江口水库供水对象包含汉江中下游、清泉沟及南水北调中线一期工程三部分 ${ }^{[1]}$, 其供水调度关系到 汉江中下游、清泉沟用水安全和南水北调中线工程的正常运行, 关系到我国水资源优化配置战略格局, 也关 系到有效缓解华北地区缺水和改善生态环境战略目标的实现, 成为学界高度关注的热点和难点问题. 国内 专家和学者针对南北地区水文气象和分布特性开展了广泛的研究, 闻宝伟等 ${ }^{[2]}$ 运用 Copula 方法构建了水源 区与受水区降雨分布模型, 并对其丰枯遭遇进行了研究; 王政祥等 ${ }^{[3]}$ 采用实测降雨资料, 分析了汉江水源 区, 唐白河、淮河、海河南北受水区降水统计特征及水源区与受水区丰枯遭遇特征; 韩宇平等 ${ }^{[4]}$ 采用历年天 然径流量对水源区、受水区和黄河进行了丰枯遭遇分析, 结果表明中线工程向黄河河道相机补水是可能的. 关于丹江口水库调度方式的研究, 杨光等 ${ }^{[5]}$ 提出了 Pareto 存档动态维度搜索算法, 将其引人考虑供水和发 电的多目标优化调度模型, 构建优化丹江口水库调度图, 同时提出了考虑未来径流变化的丹江口水库多目 标调度规则 ${ }^{[6]}$; 汪芸等 ${ }^{[7]}$ 采用灵敏度分析理论, 对影响丹江口水库兴利调度的不确定因素进行了定量分析; 栗飞等 ${ }^{[8]}$ 采用了配合多目标解集的简化运行方式, 合理解决了丹江口水库多目标调度问题; 张睿等提出了 多目标兴利调度建模理论及求解方法 ${ }^{[9]}$, 并建立了丹江口多目标兴利调度决策指标体系 ${ }^{[10]}$, 采用层次分析 法对多个调度方案进行评价和决策,得到多目标兴利调度方案的均衡解.

相关专家和学者围绕南北降雨丰枯遭遇和丹江口水库调度问题进行大量积极有益的探索, 然而已有研 究主要围绕水源区与受水区水文特性分析, 或水库综合调度及求解算法, 未能实现两研究领域的有机融合, 针对南北同枯这一特殊水文情势对水库调度的影响及南北同枯场景下丹江口水库调度方式的研究尚未涉 及, 在一定程度上限制了丹江口水库供水效益的发挥. 因此, 本文在总结分析南水北调中线工程通水后丹江 口水库供水现状及面临问题的基础上,提出了南北同枯的定义特征、判别标准及对供水水库的影响程度, 阐 明南北同枯场景下水库调度方式研究的迫切需求; 在此基础上, 探讨了水库供水起始水位对汉江中下游、清 泉沟和南水北调中线供水的影响程度, 提出南北同枯场景下丹江口水库 “蓄丰补枯、均衡减少” 供水调度方 式,并对不同供水起始水位、调度方式情况下供水效益进行比较, 研究成果可对目前丹江口水库已有供水调 度方式形成补充和完善, 为今后南水北调中线工程和丹江口水库的运行调度提供一定的指导和借鉴.

\section{1 通水后丹江口水库供水现状及影响因素}

南水北调中线工程连接“长江经济带”和“京津冀协同发展”两大国家战略, 汉江中下游地处“推进汉江 生态经济带建设”、“两圈两带”等湖北区域发展战略核心区域, 新形势下水源区及受水区社会经济高速发展 为丹江口水库供水提出了更高要求. 因此, 汉江流域水资源配置及丹江口水库水量调度问题已经由本流域、 单一水库的技术问题转变为跨流域、多尺度、工程社会效益并重的复杂决策问题,迫切需要以南水北调中线 工程及丹江口水库的供水现状为切人点, 通过分析近年水文情势变化规律和供水调度面临的技术难题, 为 南北同枯场景下水库供水调度方式的提出奠定良好的基础.

\section{1 南水北调中线通水后丹江口水库供水现状}

丹江口大坝加高工程完建后, 供水成为丹江口水库的首要兴利任务. 根据国务院令第 647 号《南水北调 工程供用水管理条例》,中线工程的供水年度为每年 11 月至次年 10 月. 自 2014 年 12 月 12 日南水北调中线 工程正式通水以来, 目前两个供水年度已结束. 在连续来水偏枯的情况下, 丹江口水库 $2014-2015$ 年供水 $332.85 \times 10^{8} \mathrm{~m}^{3}, 2015-2016$ 年累计供水 $198.44 \times 10^{8} \mathrm{~m}^{3}$, 经陶岔渠首枢纽累计向北方供水达 $60.12 \times 10^{8} \mathrm{~m}^{3}$, 各 年供水量情况见表 1 .

\section{2 供水影响成因分析}

1) 人库来水持续偏枯. 南水北调中线一期工程采用 1954-1998 年系列作为设计人库径流系列. 已有研 
表 1 南水北调中线通水后丹江口水库供水水量

Tab.1 Water supply of Danjiangkou Reservoir after implementation of South-to-North Water Diversion Middle Route Project

\begin{tabular}{ccccc}
\hline 调水年度 & 汉江中下游 $/\left(\times 10^{8} \mathrm{~m}^{3}\right)$ & 清泉沟 $/\left(\times 10^{8} \mathrm{~m}^{3}\right)$ & 陶岔 $/\left(\times 10^{8} \mathrm{~m}^{3}\right)$ & 年度总供水量 $/\left(\times 10^{8} \mathrm{~m}^{3}\right)$ \\
\hline $2014-2015$ 年 & 301.28 & 9.34 & 21.67 & 332.85 \\
$2015-2016$ 年 & 145.78 & 14.21 & 38.45 & 198.44 \\
合计 & 447.06 & 23.55 & 60.12 & 531.29 \\
\hline
\end{tabular}

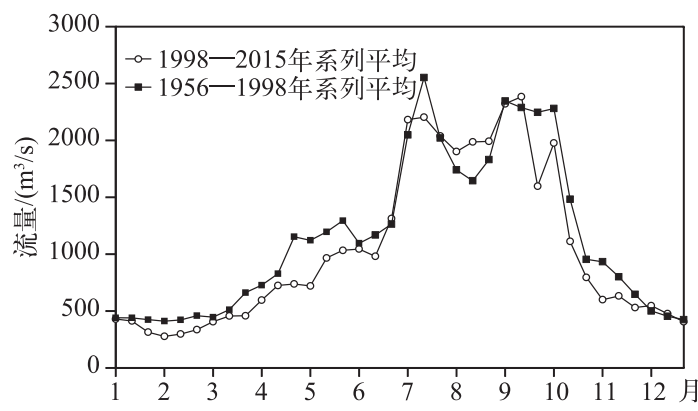

图 1 不同系列人库来水比较

Fig.1 Comparison of different incoming water into reservoir
究表明,1998 年以来丹江口水库实际人库来水较设 计径流系列水平持续减少 ${ }^{[11]}$. 研究统计了 19561998 年设计人库径流系列和 $1998-2015$ 年实际人 库,月平均分布如图 1 所示. 分析表明,1956-1998 年设计径流系列多年平均人库水量 $361.48 \times 10^{8} \mathrm{~m}^{3}$, 而 1998-2015 年丹江口年均人库水量 $325.87 \times 10^{8}$ $\mathrm{m}^{3}$, 相比设计系列减少近 9.9\%. 尤其是 2015-2016 年,丹江口水库实际人库水量 $215.36 \times 10^{8} \mathrm{~m}^{3}$, 较多 年均偏少 $39.5 \%$, 属来水特枯年份, 极大地影响了水 源区、受水区的供水安全和水库综合效益的发挥.

2) 水源区、受水区用水需求逐步增加. 受到降 雨减少影响,湖北省西北部在 2014、2016、2017 年夏 季相继发生严重的干旱灾害,对十堰、襄阳地区的

生活生产带来较大影响. 自丹江口水库进人后期规模正常运行期以来, 北方受水区计划调水量逐步增加, 2016 年局部区域出现实际供水量超过水利部批复的计划供水量的现象. 汉江中下游因来水减少和调水影 响,部分江段在春季发生轻度“水华”. 汉江流域供水与抗旱、南水北调中线一期工程供水、防范水污染事件 等一系列问题对丹江口水库供水调度提出了更高的要求.

3) 长期预报风险较大. 受限于传统长期径流预报技术水平, 以年为预报时段的长期预报过程目前难以 满足实际调度的精度要求. 对比 2014-2015 和 2015-2016 年两个调水年度丹江口水库来水情况可以发现, 实际人库较预报来水在年度水量和分布过程上均存在一定误差, 这对水库供水调度的实施提出了极大挑战.

综上分析, 受到人库来水减少、用水需求持续增加、长期预报风险等方面综合影响, 以及不同流域、区域 水文情势差异的制约,丹江口水库在未来的运行调度过程中可能出现水源区和受水区同时遭遇连续枯水年 或枯水时段, 水源工程在预见期内人库径流和存蓄水量难以充分满足水源区和受水区正常用水要求,出现 设计保证率以外、对正常供水较为不利的南北同枯场景. 当遭遇南北同枯场景时,若仍按正常运行方式进行 水库调度, 可能出现供水不足甚至影响生活、生产、生态用水安全. 为此, 分析南北同枯场景对丹江口水库供 水的影响程度, 进而提出相应的供水调度策略, 是当前南水北调中线水源工程亟待解决的关键问题, 也是本 文力图解决的技术难题.

\section{2 南北同枯场景下水库供水方法的提出}

南北同枯场景下水库供水运用方式应以调度周期整体供水效益为目标, 统筹协调不同供水时段、不同 供水对象间的耦合制约关系，缓解供水破坏带来的不利影响. 当预报水源区将遭遇枯水年,而受水区因降水 极少用水需求逐步增加时, 按年度供水计划要求的水量向供水对象正常供水, 若超过水库调蓄能力, 水库水 位将快速消落至死水位, 造成后期无水可供的极端破坏情况. 如针对可能出现的南北同枯场景对水库设定 相应的预警判断水位, 当供水期初水位低于供水预警水位即开始采取减少前期供水, 为后续时段预留足够 的蓄水水量, 从而在保障水库持续供水的同时,避免了快速消落带来的极端供水破坏风险. 这是南北同枯场 景下丹江口水库供水调度的基本原则. 


\section{1 南北同枯供需分析}

为分析南北同枯情景下水库所面临的调度问题,同时保持和前期设计、研究成果的延续性,本文首先就 1956-1998 年设计径流系列来水情势和需水情况进行分析,提出来水量枯、需水量大的 “南北同枯”场景调 度典型水文年. 南北同枯场景涉及水源工程来水偏枯和受水区枯水两方面影响: 水源区来水偏枯, 意味着丹 江口水库可供水量偏少; 受水区枯水, 意味着需丹江口水库经南水北调中线工程供水水量较大. 因此, 南北 同枯场景的频率标准有别于传统单一流域来水频率. 考虑到丹江口水库三供水对象中汉江中下游需供水水 量最大, 陶岔次之, 清泉沟引水水量影响较小, 本文拟定南北同枯的组合频率判断标准为: (1) 丹江口人库来 水频率大于 $50 \%$; (2)汉江中下游需水频率大于 $50 \%$; (3) 南水北调中线需水频率大于 $50 \%$. 满足上述来、需水 组合频率标准, 可判断为丹江口水库遭遇了南北同枯情景.

采用水利部水建管 [2016] 377 号文批复的 《丹江口水利枢纽调度规程 (试行)》提出的供水 调度方式对设计径流过程进行模拟供水调度计 算. 根据调度规程要求,丹江口水利枢纽按丹江 口水库预报来水、水库水位, 结合汉江中下游、清 泉沟和陶岔供水需调水量, 按库水位高低, 以供 水调度线作为控制水位, 进行分区供水调度. 由 此得到典型水文年及供水调度结果见表 2、3.

南北同枯场景下丹江口水库供水情势呈现 以下特点: (1) 当遭遇南北同枯场景时, 通过丹江 口水库的调蓄, 汉江中下游、清泉沟供水基本能 满足需水要求, 仅 1965 年出现汉江中下游、清泉 沟供水不足. 南水北调中线供水方面, 当受水区 需水频率大于 $65 \%$ 时, 即年需水量大于 $102 \times 10^{8}$ $\mathrm{m}^{3}$ 时, 中线供水量出现不同程度的缺水; (2) 南北 同枯场景各典型年初始水位均在 $160 \mathrm{~m}$ 以上, 年 内水库蓄水量较为充裕, 因而经过供水年度后, 年末水位均在 $155 \mathrm{~m}$ 以上, 仍有较大幅度满足三 方供水需求 (表 2、表 3 ). 上述计算结果表明,当 预报将遭遇南北同枯场景时, 水库预留足够蓄水 水量可较好地满足次年南北同枯场景下汉江中 下游、清泉沟、南水北调中线工程供水要求.

\section{2 南北同枯场景下水库供水方法的提出}

依据前述南北同枯调水调度模拟成果可知, 当初始水位在 $160 \mathrm{~m}$ 以上时, 能较好的满足当年 的供水要求. 为进一步分析南北同枯场景下水库 供水调度的应对策略, 本文将从以下两个方面展 开研究: (1) 将遭遇南北同枯场景下的丹江口水 库作为研究对象, 以不同典型年来水和设计需水

表 2 南北同枯场景下丹江口典型年来、需水情况

Tab.2 Incoming and requirement of water supply under water shortage of South and North

\begin{tabular}{ccccc}
\hline \multirow{2}{*}{ 水文年 } & 来水频率/ & \multicolumn{3}{c}{ 需水频率 $/ \%$} \\
\cline { 3 - 5 } & $\%$ & 汉江中下游 & 清泉沟 & 南水北调中线 \\
\hline 1958 & 79.07 & 95.35 & 7.49 & 44.19 \\
1960 & 46.51 & 93.02 & 97.67 & 86.05 \\
1961 & 74.42 & 83.72 & 90.70 & 58.14 \\
1965 & 97.67 & 97.67 & 93.02 & 55.81 \\
1971 & 60.47 & 62.79 & 27.91 & 65.12 \\
1987 & 62.79 & 60.47 & 37.21 & 79.07 \\
1985 & 86.05 & 81.40 & 48.84 & 83.72 \\
1992 & 53.49 & 79.07 & 41.86 & 93.02 \\
1993 & 88.37 & 74.42 & 23.26 & 62.79 \\
\hline
\end{tabular}

表 3 南北同枯场景典型年供水调度情况

Tab.3 Water supply under water shortage of South and North

\begin{tabular}{|c|c|c|c|c|c|}
\hline \multirow[b]{2}{*}{ 水文年 } & \multirow{2}{*}{$\begin{array}{c}\text { 年初水位/ } \\
\mathrm{m}\end{array}$} & \multirow{2}{*}{$\begin{array}{c}\text { 年末水位/ } \\
\mathrm{m}\end{array}$} & \multicolumn{3}{|c|}{ 供水量一需水水量 $/\left(\times 10^{8} \mathrm{~m}^{3}\right)$} \\
\hline & & & $\begin{array}{c}\text { 汉江中 } \\
\text { 下游 }\end{array}$ & 清泉沟 & $\begin{array}{l}\text { 南水北 } \\
\text { 调中线 }\end{array}$ \\
\hline 1958 & 165.86 & 155.78 & 12.11 & 0.62 & 3.83 \\
\hline 1960 & 163.45 & 164.63 & 10.84 & -1.09 & -5.80 \\
\hline 1961 & 164.63 & 160.29 & 22.02 & -0.13 & 0.29 \\
\hline 1965 & 164.55 & 152.47 & -28.98 & -0.26 & 0.76 \\
\hline 1971 & 165.08 & 159.38 & 46.37 & 2.72 & -0.72 \\
\hline 1985 & 165.88 & 159.54 & 14.09 & 1.97 & -3.47 \\
\hline 1987 & 161.52 & 163.33 & 13.07 & 1.39 & -8.26 \\
\hline 1992 & 161.94 & 160.28 & 56.82 & 1.56 & -12.88 \\
\hline 1993 & 160.28 & 156.55 & -4.61 & 1.90 & -7.42 \\
\hline
\end{tabular}
为输人, 研究丹江口水库供水能力对不同起始水位的敏感程度, 提出影响南北同枯场景下水库正常供水的 预警控制水位; (2) 定量分析丹江口水库在不同初始水位与供水控制方式组合对汉江中下游、清泉沟、南水 北调中线供水的影响程度,探究兼顾供水效益和减少供水破坏深度的水库供水调度方式,为南北同枯场景 下丹江口水库供水调度策略的制定提供理论依据和科学指导. 


\section{3 起始水位对供水调度的影响研究}

为分析起始水位对南北同枯场景水库供水调度的影响,并提出有效的应对对策,有必要对上述南北同 枯场景典型水文年进行深人研究. 通过拟定不同起始水位, 进行典型枯水段供水调度计算, 综合比选各方案 的供水量、供水过程及破坏深度, 找出南北同枯场景水库供水调度的预警控制水位, 为提出避免供水出现极 端破坏的应对策略提供技术支持. 为此, 本文拟定丹江口水库起始水位 $157 、 156 、 155 、 154 、 153 、 152 、 151 、 150$

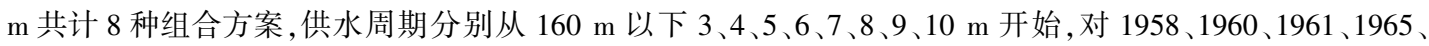
1971、1985、1987、1992、1993 年共 9 场南北同枯场景的典型年进行供水调度计算, 结果见表 4、表 5.

表 4 初始水位 $157 、 156 、 155 、 154 \mathrm{~m}$ 供水调度结果

Tab.4 Scheduling results at initial water levels of 157, 156, 155 and $154 \mathrm{~m}$

\begin{tabular}{|c|c|c|c|c|c|c|c|c|c|c|c|c|}
\hline \multirow{3}{*}{ 水文年 } & \multicolumn{6}{|c|}{ 初始水位 $157 \mathrm{~m}$} & \multicolumn{6}{|c|}{ 初始水位 $156 \mathrm{~m}$} \\
\hline & \multicolumn{3}{|c|}{ 水位 $/ \mathrm{m}$} & \multicolumn{3}{|c|}{ 最小供水流量 $/\left(\mathrm{m}^{3} / \mathrm{s}\right)$} & \multicolumn{3}{|c|}{ 水位 $/ \mathrm{m}$} & \multicolumn{3}{|c|}{ 最小供水流量 $/\left(\mathrm{m}^{3} / \mathrm{s}\right)$} \\
\hline & 年初 & 年末 & 最低 & $\begin{array}{c}\text { 汉江 } \\
\text { 中下游 }\end{array}$ & 清泉沟 & $\begin{array}{l}\text { 南水北 } \\
\text { 调中线 }\end{array}$ & 年初 & 年末 & 最低 & $\begin{array}{c}\text { 汉江中 } \\
\text { 下游 }\end{array}$ & 清泉沟 & $\begin{array}{l}\text { 南水北 } \\
\text { 调中线 }\end{array}$ \\
\hline 1958 & 157.00 & 155.33 & 155.33 & 490 & 12 & 240 & 156.00 & 154.82 & 154.46 & 490 & 14 & 240 \\
\hline 1960 & 157.00 & 164.63 & 150.75 & 490 & 14 & 227 & 156.00 & 163.92 & 149.12 & 490 & 4 & 230 \\
\hline 1961 & 157.00 & 158.20 & 150.27 & 490 & 14 & 230 & 156.00 & 157.59 & 149.37 & 490 & 14 & 229 \\
\hline 1965 & 157.00 & 147.10 & 146.43 & 400 & 4 & 152 & 156.00 & 146.89 & 145.85 & 392 & 4 & 116 \\
\hline 1971 & 157.00 & 159.38 & 155.71 & 490 & 12 & 240 & 156.00 & 159.00 & 154.91 & 490 & 14 & 240 \\
\hline 1985 & 157.00 & 154.45 & 150.52 & 490 & 14 & 230 & 156.00 & 152.99 & 149.17 & 490 & 4 & 263 \\
\hline 1987 & 157.00 & 161.50 & 146.24 & 490 & 4 & 133 & 156.00 & 161.38 & 145.87 & 419 & 4 & 112 \\
\hline 1992 & 157.00 & 159.69 & 148.97 & 490 & 6 & 230 & 156.00 & 160.21 & 148.20 & 490 & 4 & 251 \\
\hline \multirow[t]{2}{*}{1993} & 157.00 & 154.19 & 150.19 & 490 & 14 & 230 & 156.00 & 152.47 & 148.51 & 490 & 4 & 256 \\
\hline & \multicolumn{6}{|c|}{ 初始水位 $155 \mathrm{~m}$} & \multicolumn{6}{|c|}{ 初始水位 $154 \mathrm{~m}$} \\
\hline \multirow{2}{*}{ 水文年 } & \multicolumn{3}{|c|}{ 水位 $/ \mathrm{m}$} & \multicolumn{3}{|c|}{ 最小供水流量 $/\left(\mathrm{m}^{3} / \mathrm{s}\right)$} & \multicolumn{3}{|c|}{ 水位 $/ \mathrm{m}$} & \multicolumn{3}{|c|}{ 最小供水流量/( m³/s) } \\
\hline & 年初 & 年末 & 最低 & $\begin{array}{c}\text { 汉江 } \\
\text { 中下游 }\end{array}$ & 清泉沟 & $\begin{array}{l}\text { 南水北 } \\
\text { 调中线 }\end{array}$ & 年初 & 年末 & 最低 & $\begin{array}{c}\text { 汉江 } \\
\text { 中下游 }\end{array}$ & 清泉沟 & $\begin{array}{l}\text { 南水北 } \\
\text { 调中线 }\end{array}$ \\
\hline 1958 & 155.00 & 154.00 & 153.41 & 490 & 14 & 240 & 154.00 & 153.34 & 152.40 & 490 & 2 & 240 \\
\hline 1960 & 155.00 & 164.23 & 148.04 & 400 & 4 & 256 & 154.00 & 163.98 & 147.45 & 400 & 2 & 214 \\
\hline 1961 & 155.00 & 156.61 & 147.98 & 400 & 14 & 229 & 154.00 & 156.15 & 147.21 & 400 & 15 & 197 \\
\hline 1965 & 155.00 & 146.75 & 145.47 & 400 & 2 & 85 & 154.00 & 146.67 & 145.23 & 392 & 2 & 66 \\
\hline 1971 & 155.00 & 158.61 & 154.47 & 490 & 14 & 240 & 154.00 & 157.83 & 153.45 & 490 & 14 & 230 \\
\hline 1985 & 155.00 & 152.30 & 148.06 & 490 & 4 & 254 & 154.00 & 151.15 & 147.08 & 490 & 2 & 193 \\
\hline 1987 & 155.00 & 161.27 & 145.55 & 400 & 2 & 91 & 154.00 & 161.21 & 145.35 & 392 & 2 & 77 \\
\hline 1992 & 155.00 & 159.94 & 147.50 & 400 & 2 & 212 & 154.00 & 159.69 & 147.12 & 400 & 2 & 192 \\
\hline 1993 & 155.00 & 151.82 & 147.55 & 490 & 2 & 216 & 154.00 & 151.59 & 147.24 & 490 & 2 & 198 \\
\hline
\end{tabular}

分析不同起始水位的供水调度成果可知:

1) 当遭遇南北同枯场景时, 随着水库起始水位的降低, 调度期末水位和最低水位均相应降低, 汉江中下 游、清泉沟、南水北调中线最小供水流量也逐步减少,供水破坏深度逐步增加.

2) 分析不同起始水位下丹江口水库的供水情况, 水库起始水位在 $152 \mathrm{~m}$ 以上时, 汉江中下游、清泉沟、 南水北调中线三方供水仍能保证一定供水流量; 当起始水位低于 $152 \mathrm{~m}$ 时, 按照原供水调度方式,清泉沟、 南水北调中线将出现断流的极端供水破坏情况. 由此可见, $152 \mathrm{~m}$ 可作为南北同枯场景水库供水调度的预警 控制水位, 当供水调度年度起始水位低于 $152 \mathrm{~m}$ 时, 丹江口水库须转人应对南北同枯场景的应急调度. 
表 5 初始水位 $153 、 152 、 151 、 150 \mathrm{~m}$ 供水调度结果

Tab.5 Scheduling results at initial water levels of 153, 152, 151 and $150 \mathrm{~m}$

\begin{tabular}{|c|c|c|c|c|c|c|c|c|c|c|c|c|}
\hline \multirow{3}{*}{ 水文年 } & \multicolumn{6}{|c|}{ 初始水位 $153 \mathrm{~m}$} & \multicolumn{6}{|c|}{ 初始水位 $152 \mathrm{~m}$} \\
\hline & \multicolumn{3}{|c|}{ 水位 $/ \mathrm{m}$} & \multicolumn{3}{|c|}{ 最小供水流量 $/\left(\mathrm{m}^{3} / \mathrm{s}\right)$} & \multicolumn{3}{|c|}{ 水位 $/ \mathrm{m}$} & \multicolumn{3}{|c|}{ 最小供水流量 $/\left(\mathrm{m}^{3}\right.$ /s) } \\
\hline & 年初 & 年末 & 最低 & $\begin{array}{c}\text { 汉江 } \\
\text { 中下游 }\end{array}$ & 清泉沟 & $\begin{array}{l}\text { 南水北 } \\
\text { 调中线 }\end{array}$ & 年初 & 年末 & 最低 & $\begin{array}{c}\text { 汉江 } \\
\text { 中下游 }\end{array}$ & 清泉沟 & $\begin{array}{l}\text { 南水北 } \\
\text { 调中线 }\end{array}$ \\
\hline 1958 & 153.00 & 153.22 & 151.33 & 490 & 2 & 230 & 152.00 & 152.38 & 150.31 & 490 & 2 & 230 \\
\hline 1960 & 153.00 & 163.86 & 146.99 & 400 & 2 & 187 & 152.00 & 163.75 & 146.55 & 400 & 2 & 161 \\
\hline 1961 & 153.00 & 155.86 & 146.45 & 392 & 2 & 145 & 152.00 & 155.70 & 146.02 & 400 & 2 & 118 \\
\hline 1965 & 153.00 & 146.62 & 145.07 & 392 & 2 & 53 & 152.00 & 146.60 & 145.00 & 389 & 0 & 0 \\
\hline 1971 & 153.00 & 157.12 & 152.43 & 490 & 14 & 230 & 152.00 & 157.46 & 151.45 & 490 & 2 & 230 \\
\hline 1985 & 153.00 & 150.94 & 146.73 & 490 & 2 & 173 & 152.00 & 150.74 & 146.41 & 490 & 2 & 152 \\
\hline 1987 & 153.00 & 161.21 & 145.24 & 392 & 2 & 70 & 152.00 & 161.21 & 145.00 & 400 & 2 & 53 \\
\hline 1992 & 153.00 & 160.48 & 146.46 & 400 & 2 & 155 & 152.00 & 160.24 & 145.77 & 400 & 2 & 112 \\
\hline \multirow[t]{2}{*}{1993} & 153.00 & 151.45 & 146.94 & 400 & 2 & 183 & 152.00 & 151.28 & 146.38 & 400 & 2 & 148 \\
\hline & \multicolumn{6}{|c|}{ 初始水位 $151 \mathrm{~m}$} & \multicolumn{6}{|c|}{ 初始水位 $150 \mathrm{~m}$} \\
\hline \multirow[t]{2}{*}{ 水文年 } & \multicolumn{3}{|c|}{ 水位 $/ \mathrm{m}$} & \multicolumn{3}{|c|}{ 最小供水流量 $/\left(\mathrm{m}^{3} / \mathrm{s}\right)$} & \multicolumn{3}{|c|}{ 水位 $/ \mathrm{m}$} & \multicolumn{3}{|c|}{ 最小供水流量 $/\left(\mathrm{m}^{3} / \mathrm{s}\right)$} \\
\hline & 年初 & 年末 & 最低 & $\begin{array}{c}\text { 汉江 } \\
\text { 中下游 }\end{array}$ & 清泉沟 & $\begin{array}{l}\text { 南水北 } \\
\text { 调中线 }\end{array}$ & 年初 & 年末 & 最低 & $\begin{array}{c}\text { 汉江 } \\
\text { 中下游 }\end{array}$ & 清泉沟 & $\begin{array}{l}\text { 南水北 } \\
\text { 调中线 }\end{array}$ \\
\hline 1958 & 151.00 & 151.25 & 148.94 & 490 & 2 & 230 & 150.00 & 150.90 & 148.49 & 490 & 2 & 230 \\
\hline 1960 & 151.00 & 163.60 & 146.01 & 400 & 2 & 127 & 150.00 & 163.48 & 145.56 & 400 & 2 & 94 \\
\hline 1961 & 151.00 & 155.46 & 145.55 & 392 & 2 & 84 & 150.00 & 155.33 & 145.29 & 400 & 2 & 65 \\
\hline 1965 & 151.00 & 146.60 & 145.00 & 377 & 0 & 0 & 150.00 & 146.60 & 145.00 & 335 & 0 & 0 \\
\hline 1971 & 151.00 & 156.64 & 150.43 & 490 & 2 & 230 & 150.00 & 156.85 & 149.18 & 490 & 2 & 230 \\
\hline 1985 & 151.00 & 150.67 & 146.01 & 452 & 2 & 127 & 150.00 & 150.67 & 145.66 & 400 & 2 & 102 \\
\hline 1987 & 151.00 & 161.21 & 145.00 & 392 & 0 & 0 & 150.00 & 161.21 & 145.00 & 400 & 0 & 0 \\
\hline 1992 & 151.00 & 160.10 & 145.33 & 400 & 2 & 76 & 150.00 & 160.00 & 145.00 & 400 & 0 & 0 \\
\hline 1993 & 151.00 & 151.22 & 145.75 & 400 & 2 & 106 & 150.00 & 151.08 & 145.32 & 400 & 2 & 71 \\
\hline
\end{tabular}

\section{4 南北同枯场景丹江口水利枢纽供水调度方式}

为避免遭遇南北同枯场景南水北调中线及丹江口水库可能出现的极端供水破坏, 本文提出南北同枯场景 丹江口水利枢纽供水调度方式: 当预报将遭遇南北同枯场景, 且丹江口水库起始水位低于预警控制水位 $152 \mathrm{~m}$ 时,丹江口水库采取 “蓄丰补枯、均衡减少” 的方法, 在供水调度年度前期即开始降低汉江中下游、清泉沟、陶岔 三供水方向需供水, 从而保障不同供水对象的持续性供水. 为此, 本文针对原调度规程中供水调度方式中拟定 的供水流量,拟定 $20 \% 、 40 \%$ 两种降低幅度,均衡降低汉江中下游、清泉沟、南水北调中线供水流量.

由于篇幅所限,仅针对前述初始水位中出现极端供水破坏的 $152 、 150 \mathrm{~m}$ 调度方案进行均衡降低供水的 模拟计算,其他初始水位的研究方法类似. 依据起始水位和降低供水方式的不同组合, 分别拟定 4 个南北同 枯场景下供水调度方案( 表 6).

表 6 南北同枯场景下供水调度方案拟定

Tab.6 Operation schemes under water shortage of South and North

\begin{tabular}{ccccc}
\hline 方案编号 & 方案 I & 方案 II & 方案 III & 方案IV \\
\hline 初始水位 & $152 \mathrm{~m}$ & $152 \mathrm{~m}$ & $150 \mathrm{~m}$ & $150 \mathrm{~m}$ \\
降低幅度 & 降低 $20 \%$ & 降低 $40 \%$ & 降低 $20 \%$ & 降低 $40 \%$ \\
\hline
\end{tabular}


根据上述拟定的 4 个南北同枯场景下运行方式方案, 分别以 11 月至次年 10 月为调度周期进行供水调 度计算, 得到起始水位分别为 $152 、 150 \mathrm{~m}$ 时的调度结果 (表 7). 对比方案 I IV 计算结果可知: 当预报将遭 遇南北同枯场景, 且水库起始水位低于 $152 \mathrm{~m}$ 时, 汉江中下游、清泉沟、南水北调中线通过 “蓄丰补枯、均衡 减少” 的方式统一降低供水, 能有效避免极端供水破坏情况, 三供水方向均能保证稳定的供水流量. 随着供 水降低幅度的增加, 年末水位和最低水位均相应提高, 但最小供水流量也相应降低. 年末水位取决于年内总 水量的平衡关系, 而年内最小供水流量则主要受到年内来水不均影响, 这是造成极端供水破坏的主要原因. 因此, 从最大程度的缓解南北同枯场景下水源区和受水区的供水不足, 和避免供水极端破坏两方面考虑, 汉 江中下游、清泉沟、南水北调三供水方向统一按降低 $20 \%$ 供水方案优. 根据《南水北调工程供用水管理条例》 和《南水北调中线一期工程水量调度方案 (试行)》(水资源〔 2014〕337 号) 要求, 丹江口执行年度供水调度 前, 长江水利委员会提出丹江口水库上游来水预测, 湖北省及北方受水区提出需水预测, 来水和需水预测可 作为本调度方式中预报南北同枯场景的判断依据.

表 7 方案 I 、方案 II 的供水调度结果

Tab.7 Scheduling results of Scheme I and II

\begin{tabular}{|c|c|c|c|c|c|c|c|c|c|c|c|c|}
\hline \multirow{3}{*}{ 水文年 } & \multicolumn{6}{|c|}{ 方案 I : 降低 20\% } & \multicolumn{6}{|c|}{ 方案 II : 降低 40\% } \\
\hline & \multicolumn{3}{|c|}{ 水位 $/ \mathrm{m}$} & \multicolumn{3}{|c|}{ 最小供水流量 $/\left(\mathrm{m}^{3} / \mathrm{s}\right)$} & \multicolumn{3}{|c|}{ 水位 $/ \mathrm{m}$} & \multicolumn{3}{|c|}{ 最小供水流量 $/\left(\mathrm{m}^{3} / \mathrm{s}\right)$} \\
\hline & 年初 & 年末 & 最低 & $\begin{array}{l}\text { 汉江 } \\
\text { 中下游 }\end{array}$ & 清泉沟 & $\begin{array}{l}\text { 南水北 } \\
\text { 调中线 }\end{array}$ & 年初 & 年末 & 最低 & $\begin{array}{c}\text { 汉江 } \\
\text { 中下游 }\end{array}$ & 清泉沟 & $\begin{array}{l}\text { 南水北 } \\
\text { 调中线 }\end{array}$ \\
\hline 1958 & 152.00 & 158.47 & 152.56 & 400 & 1 & 192 & 152.00 & 159.99 & 152.77 & 196 & 1 & 136 \\
\hline 1960 & 152.00 & 165.91 & 149.16 & 400 & 1 & 181 & 152.00 & 167.06 & 152.58 & 282 & 1 & 136 \\
\hline 1961 & 152.00 & 160.55 & 151.00 & 400 & 1 & 184 & 152.00 & 164.41 & 153.56 & 294 & 1 & 144 \\
\hline 1965 & 152.00 & 148.67 & 147.23 & 314 & 1 & 158 & 152.00 & 155.91 & 151.95 & 294 & 1 & 138 \\
\hline 1971 & 152.00 & 160.95 & 154.66 & 369 & 1 & 181 & 152.00 & 162.32 & 154.97 & 294 & 1 & 136 \\
\hline 1985 & 152.00 & 157.18 & 149.72 & 400 & 1 & 195 & 152.00 & 162.21 & 152.85 & 245 & 1 & 138 \\
\hline 1987 & 152.00 & 163.98 & 147.53 & 320 & 1 & 183 & 152.00 & 165.10 & 150.45 & 294 & 1 & 138 \\
\hline 1992 & 152.00 & 161.78 & 148.10 & 320 & 1 & 184 & 152.00 & 163.66 & 150.00 & 160 & 1 & 136 \\
\hline 1993 & 152.00 & 156.76 & 149.07 & 400 & 1 & 184 & 152.00 & 160.59 & 152.09 & 281 & 1 & 136 \\
\hline \multirow{3}{*}{ 水文年 } & \multicolumn{6}{|c|}{ 方案 III : 降低 20\% } & \multicolumn{6}{|c|}{ 方案IV : 降低 40\% } \\
\hline & \multicolumn{3}{|c|}{ 水位 $/ \mathrm{m}$} & \multicolumn{3}{|c|}{ 最小供水流量 $/\left(\mathrm{m}^{3} / \mathrm{s}\right)$} & \multicolumn{3}{|c|}{ 水位 $/ \mathrm{m}$} & \multicolumn{3}{|c|}{ 最小供水流量 $/\left(\mathrm{m}^{3} / \mathrm{s}\right)$} \\
\hline & 年初 & 年末 & 最低 & $\begin{array}{c}\text { 汉江 } \\
\text { 中下游 }\end{array}$ & 清泉沟 & $\begin{array}{l}\text { 南水北 } \\
\text { 调中线 }\end{array}$ & 年初 & 年末 & 最低 & $\begin{array}{c}\text { 汉江 } \\
\text { 中下游 }\end{array}$ & 清泉沟 & $\begin{array}{l}\text { 南水北 } \\
\text { 调中线 }\end{array}$ \\
\hline 1958 & 150.00 & 157.43 & 150.61 & 400 & 1 & 192 & 150.00 & 159.99 & 150.83 & 294 & 1 & 136 \\
\hline 1960 & 150.00 & 165.91 & 147.99 & 400 & 1 & 181 & 150.00 & 167.06 & 150.63 & 282 & 1 & 136 \\
\hline 1961 & 150.00 & 159.16 & 148.98 & 400 & 1 & 183 & 150.00 & 163.88 & 151.69 & 210 & 1 & 152 \\
\hline 1965 & 150.00 & 148.05 & 146.48 & 314 & 1 & 149 & 150.00 & 154.34 & 150.16 & 200 & 1 & 138 \\
\hline 1971 & 150.00 & 160.95 & 152.90 & 369 & 1 & 181 & 150.00 & 162.32 & 153.19 & 294 & 1 & 136 \\
\hline 1985 & 150.00 & 155.82 & 148.26 & 400 & 1 & 189 & 150.00 & 162.01 & 150.92 & 294 & 1 & 138 \\
\hline 1987 & 150.00 & 163.53 & 146.49 & 320 & 1 & 153 & 150.00 & 165.10 & 149.31 & 240 & 1 & 138 \\
\hline 1992 & 150.00 & 161.25 & 146.32 & 320 & 1 & 140 & 150.00 & 163.66 & 148.75 & 240 & 1 & 136 \\
\hline 1993 & 150.00 & 155.52 & 147.56 & 320 & 1 & 189 & 150.00 & 160.59 & 150.10 & 281 & 1 & 138 \\
\hline
\end{tabular}

\section{5 结论}

在南水北调中线工程通水后丹江口水库供水现状的基础上, 阐明了南北同枯的特征定义、判别标准及 供水调度面临的问题, 定量描述了起始供水水位对汉江中下游、清泉沟和南水北调中线供水的影响程度, 提 出南北同枯场景下丹江口水库 “蓄丰补枯、均衡减少” 供水调度方式, 并对不同供水起始水位、不同供水方式 
情况下供水效益进行比较,得到如下结论：

1) 受到人库来水减少、用水需求持续增加、长期预报风险等方面综合影响, 丹江口水库在未来的运行调 度过程中可能出现南北同枯调度场景.

2) 南北同枯场景下丹江口水库供水调度的预警控制水位为 $152 \mathrm{~m}$. 根据汉江流域水雨情和受水区需水 预测, 当预报水源区与受水区将同时遭遇枯水, 且供水调度年度起始水位低于 $152 \mathrm{~m}$ 时, 丹江口水库需转人 应对南北同枯场景的应急调度.

3) 当预报将遭遇南北同枯场景, 且丹江口 11 月初水位低于 $152 \mathrm{~m}$ 时, 水库采取 “蓄丰补枯、均衡减少” 的方法, 降低汉江中下游、清泉沟、南水北调中线供水流量, 可有效缓解面临时段至余留期供水破坏深度, 保 障水源区及受水区的供水安全.

\section{6 参考文献}

[ 1 ] Wang Hao, Zheng Hezhen, Lei Xiaohui et al. Study on key technologies of emergency regulation and treatment to ensure water quality safety of the main canal of middle routes of South-to-North water diversion project. Journal of Sichuan University: Engineering Science Edition, 2016, 48(2) : 1-6. [王浩, 郑和震, 雷晓辉等. 南水北调中线干线水质安全应急 调控与处置关键技术研究. 四川大学学报: 工程科学版, 2016, 48(2) : 1-6.]

[ 2 ] Yan Baowei, Guo Shenglian, Xiao Yi. Synchronous-asynchronous encounter probability of rich-poor precipitation between water source area and water receiving areas in the Middle Route of South-to-North Water Transfer Project. Journal of $\mathrm{Hy}$ draulic Engineering, 2007, 38(10): 1178-1185. [闰宝伟, 郭生练, 肖义. 南水北调中线水源区与受水区降水丰枯 遭遇研究. 水利学报, 2007, 38(10): 1178-1185.]

[ 3 ] Wang Zhengxiang, Zhang Mingbo. Analysis on wetness-dryness encountering of runoff flow between water source region and receiving water region in the middle route of the South-to-North Water Transfer Project. Yangtze River, 2008, 39(17): 103-105. [王政祥, 张明波. 南水北调中线水源与受水区降水丰枯遭遇分析. 人民长江, 2008, 39(17) : 103-105.]

[ 4 ] Han Yuping, Jiang Renfei, Ruan Benqing. Analysis on wetness-dryness encountering of runoff flow between water source region and receiving water region in the middle route of the South-to-North Water Transfer Project. Journal of North China Institute of Water Conservancy and Hydroelectric Power, 2007, 28(1) : 8-11. [ 韩宇平, 蒋任飞, 阮本清. 南水北调中线 水源区与受水区丰枯遭遇分析. 华北水利水电学院学报, 2007, 28(1): 8-11.]

[ 5 ] Yang Guang, Guo Shenglian, Liu Pan et al. PA-DDS algorithm for multi-objective reservoir operation. Journal of Hydraulic Engineering, 2016, 47 (6): 789-797. [ 杨光, 郭生练, 刘攀等. PA-DDS 算法在水库多目标优化调度中的应用. 水利 学报, 2016, 47(6): 789-797.]

[ 6 ] Yang Guang, Guo Shenglian, Li Liping et al. Multi-objective operation rules for Danjiangkou Reservoir under future runoff changes. Journal of Hydroelectric Engineering, 2015, 34(12) : 54-63. [ 杨光, 郭生练, 李立平等. 考虑未来径流变化 的丹江口水库多目标调度规则研究. 水力发电学报, 2015, 34(12): 54-63.]

[ 7 ] Wang Yun, Guo Jiali, Guo Shenglian et al. Uncertainty analysis of long-term benenciai operation for Danjiangkou Reservoir. Water Power, 2016, 42(7) : 97-102. [汪芸, 郭家力, 郭生练等. 丹江口水库长期兴利调度的不确定性分析. 水力发电, 2016, 42(7): 97-102.]

[ 8 ] Li Fei, Gao Shichun, Li Xiang. Research on multi-objective operation ways of the Danjiangkou Reservoir. China Rural Water and Hydropower, 2010, 9: 18-20. [栗飞, 高仕春, 李响. 丹江口水库多目标调度方式研究. 中国农村水利水 电, 2010, 9: 18-20.]

[ 9 ] Zhang Rui, Zhang Lisheng, Wang Xuemin et al. Model and application of multi-objective beneficial dispatch for cascade reservoirs in Jinsha River. Journal of Sichuan University: Engineering Science Edition, 2016, 48(4) : 32-37. [ 张睿, 张 利升, 王学敏等. 金沙江下游梯级水库群多目标兴利调度模型及应用. 四川大学学报: 工程科学版, 2016, 48 (4) : 32-37.]

[10] Zhang Lisheng, Zhang Rui, Wang Xuemin et al. Decision-making model on multi-objective operation of Dangjiangkou Hydropoject. Yangtze River, 2016, 47(22): 105-109. [ 张利升, 张睿, 王学敏等. 丹江口水利枢纽多目标兴利调度决策 模型. 人民长江, 2016, 47(22) : 105-109.]

[11] Zhang Lisheng, Zhang Rui, Bing Jianping et al. Characteristics research of Dangjiangkou Hydropoject incoming runoff. South-to-North Transfers and Water Science \& Technology, 2016, 14(2): 12-15. [张利升, 张睿, 酣建平等. 丹江口水 利枢纽入库径流特性规律研究. 南水北调与水利科技, 2016, 14(2): 12-15.] 